\title{
Strategi Pengembangan Daya Saing Produksi Kopi Lampung
}

\author{
Strategy for Development Production Competitiveness of Lampung Coffee
}

\author{
Ananda Leonard Arios \\ Balai Riset dan Standardisasi Industri Bandar Lampung \\ Jl by pass Soekarno Hatta KM 1 Rajabasa \\ E-mail : arios.eng@gmail.com
}

\begin{abstract}
Abstrak
Kopi merupakan suatu komoditi lokal lampung yang sudah mendunia, hal ini ditunjukkan dengan adanya indikasi geografis yang terdaftar dengan nomor IDG 0ss00000026, namun kopi lampung, terus mengalami penurunan, dimana hingga tahun 2019 tercatat mengalami penurunan hingga 6.21\% sementara lahan perkebunan mengalami penurunan sebesar 2.03\%. Tujuan dari penelitian ini adalah menentukan rumusan strategi terbik dalam pengembangan produsi kopi lampung sebagai bahan baku bagi industri produsen kopi.dengan menggunakan metode SWOT. dari analisis SWOT dirumuskan strategi berupa: meningkatkan suplai kopi untuk menjaga stabilitas harga, dan meningkatkan daya saing harga kopi domestik, membangun SDM tani yang berbasis riset dan pengembangan kopi sebagai komoditi unggulan, Peningkatan produktifitas kopi melalui penerapan teknologi dan kerjasama riset.
\end{abstract}

Kata Kunci : analisis SWOT pengembangan kopi lampung

\begin{abstract}
Coffee is a local commodity of Lampung which is worldwide, this is indicated by the geographical indications registered with IDG number Oss00000026, but coffee Lampung, continues to decline, which until 2019 was recorded to have decreased by $6.21 \%$ while plantation land decreased by $2.03 \%$. The purpose of this study is to determine the best strategic formulation in the development of the Lampung coffee production as a raw material for the coffee producer industry by using the SWOT method. From the SWOT analysis a strategy was formulated in the form of: increasing coffee supply to maintain price stability, and increasing domestic coffee price competitiveness, developing research-based agricultural HR and coffee development as superior commodities, Increasing coffee productivity through the application of technology and research collaboration.
\end{abstract}

Keywords: SWOT analysis of Lampung coffee development

\section{Pendahuluan}

Kopi merupakan suatu komoditi lokal lampung yang sudah mendunia, hal ini ditunjukkan dengan adanya indikasi geografis yang terdaftar dengan nomor IDG 000000026 tanggal 13 Mei 2014, Indikasi Geografis adalah suatu tanda yang menunjukkan daerah asal suatu barang dan/atau produk yang karena faktor lingkungan geografis termasuk faktor alam, faktor manusia atau kombinasi dari kedua faktor tersebut memberikan reputasi, kualitas, dan karakteristik tertentu pada barang dan/atau produk yang dihasilkan.

Produksi kopi lampung, terus mengalami penurunan, dimana hingga tahun 2019 tercatat mengalami penurunan hingga $6.21 \%$ sementara lahan perkebunan mengalami penurunan sebesar $2.030 \%$, (direktorat jendral perkebunan kementerian perdagangan 2019). Kondisi ini membuat bahan baku untuk industri kekurangan pasokan, menurunnya produksi kopi disisi lain menimbulkan kenaikan harga kopi dilampung dan dibandingkan harga kopi impor harga kopi dilampung lebih tinggi (AEKI 2016), kondisi ini mengakibatkan kenaikan volume kopi impor yang masuk ke Indonesia pada tahun 2018 naik sebesar $554,5 \%$ mencapai 78,85 ribu ton dari sebelumnya pada 2017 meningkat sebesar 14.22 ribu ton (BPS, Statistik Kopi Indonesia 2018). Kondisi lain penguatan nilai tukar rupiah terhadap dolar juga mempengaruhi nilai ekspor dan impor komoditi (Bank Indonesia 
2019) kondisi ini membuat harga kopi impor mengalami penurunan.

\section{Metode Penelitian}

Lokasi penelitian ini dilakukan di provinsi lampung sebagai wilayah dengan penghasil kopi robusta terbesar kedua di Indonesia. Sampling pada peneletian ini dilakukan dengan metode purposive sampling dengan populasi pengusaha kopi dan petani kopi di tanggamus Ulubelu dan pengusaha kopi di Lampung sebanyak 6 (enam) sampel, adapun lingkup pertanyaan yang dituangkan mencakup faktor internal yang mempengaruhi produktifitas kopi, dan factor eksternal. Kemudian disusun sebuah pertanyaan tertutup yang mencakup variable yang dituangkan dalam table SWOT.

$$
\text { Dalam pengolahan datanya, }
$$
digunakan metode SWOT, metode ini adalah metode perencanaan strategis yang digunakan untuk mengevaluasi kekuatan (strengths), kelemahan (weaknesses), peluang (opportunities), dan ancaman (threats) dalam suatu proyek atau suatu spekulasi bisnis. Keempat faktor itulah yang membentuk akronim SWOT (strengths, weaknesses, opportunities, dan threats). SWOT akan lebih baik dibahas dengan menggunakan tabel yang dibuat dalam kertas besar, sehingga dapat dianalisis dengan baik hubungan dari setiap aspek (Rangkuti 2011). Data yang yang dihasilkan kemudian diolah menggunakan formula pada software Microsoft excel.

\section{Hasil Dan Pembahasan \\ Penentuan factor internal dan foaktor eksternal}

Perlu dilakuan identifikasi terhadap faktor internal dan eksternal dimana kedua variable ini akan menentukan strategi peningkatan daya saing kopi robusta Lampung. Faktor internal merupakan semua faktor yang dapat dikendalikan oleh system pertanian kopi itu sendiri, kemudian akan dilakukan penentuan kekuatan dan kelemahan pada sistem tani kopi robusta dalam upaya penentuan strategi pengembangan daya saingnya. Faktor eksternal mencakup semua variabel yang tidak dapat dikendalikan oleh sistem produksi pertanian kopi robusta Lampung, yang kemudian dilakukan pengklasifikasian apakah variable tersebut merupakan sebuah peluang atau ancaman bagi sistem pertanian kopi robusta (Tabel. 1).

Tabel. 1 Faktor Eksternal dan Internal Produktifitas Kopi Lampung

\begin{tabular}{|l|c|c|c|c|}
\hline \multicolumn{1}{|l|}{ Identifikasi Variabel Penelitian } & \multicolumn{2}{|c|}{$\begin{array}{c}\text { Faktor } \\
\text { Internal }\end{array}$} & \multicolumn{2}{|c|}{$\begin{array}{c}\text { Faktor } \\
\text { Eksternal }\end{array}$} \\
\hline & S & W & O & T \\
\hline Subsistem Produktifitas Kopi & & & & \\
\hline - Produktifitas lahan pertanian & & $\sqrt{ }$ & & \\
\hline - Luas lahan area tanam kopi & $\sqrt{ }$ & & & \\
\hline - Usia produktif petani & $\sqrt{ }$ & & & \\
\hline $\begin{array}{l}\text { - Penerapan teknologi dalam } \\
\text { pengelolahan lahan }\end{array}$ & & $\sqrt{ }$ & & \\
\hline $\begin{array}{l}\text { - Riset yang berkaitan dengan } \\
\text { neningkatan nroduktifitas lahan }\end{array}$ & & $\sqrt{ }$ & & \\
\hline Subsistem kualitas Produk kopi & & & & \\
\hline - Penyimpanan pasca panen & & $\sqrt{ }$ & & \\
\hline - Metedo pengeringan biji kopi & & $\sqrt{ }$ & & \\
\hline - pengemasan pada proses & & $\sqrt{ }$ & & \\
\hline Subsistem permintaan pasar & & & & \\
\hline $\begin{array}{l}\text { - Semakin banyaknya varian } \\
\text { minuman olahan kopi }\end{array}$ & & & $\sqrt{ }$ & \\
\hline - Meningkatnya konsumsi kopi & & & $\sqrt{ }$ & \\
\hline - Banyaknya coffee corner & & & $\sqrt{ }$ & \\
\hline $\begin{array}{l}\text { - Semakin banyaknya generasi } \\
\text { muda yang mulai menikmati kopi }\end{array}$ & & & $\sqrt{ }$ & \\
\hline Subsistem harga pasar Ekspor & & & & \\
\hline $\begin{array}{l}\text { - Kondisi harga dalam negeri lebih } \\
\text { tinggi dibandingkan ekspor }\end{array}$ & & & & $\sqrt{ }$ \\
\hline - Suplai impor yang sangat tinggi & & & & $\sqrt{ }$ \\
\hline $\begin{array}{l}\text { - Penguatan mata uang rupiah } \\
\text { terhadap dolar }\end{array}$ & & & & $\sqrt{ }$ \\
\hline $\begin{array}{l}\text { - Pasar produk kopi dunia yang } \\
\text { cukup besar }\end{array}$ & & & $\sqrt{ }$ & \\
\hline
\end{tabular}

\section{Tahapan Pembobotan Faktor Internal dan Eksternal}

Kemudian perlu dilakukan pembobotan faktor internal dan eksternal daya saing kopi robusta provinsi Lampun. Hal ini dilakukan untuk penentuan alternatif kebijakan yang dirumuskan dapat memberikan strategi peningkatan daya saing kopi robusta (Tabel.2). 
Tabel 2. Pembobotan Faktor Internal dan Eksternal

\begin{tabular}{|l|l|l|l|l|l|}
\hline \multicolumn{2}{|c|}{ Faktor Internal } & $\begin{array}{c}\text { Jumla } \\
\text { h }\end{array}$ & $\begin{array}{c}\text { Bobot } \\
\text { Ratin } \\
\text { g }\end{array}$ & $\begin{array}{c}\text { Bobot } \\
\text { Skor }\end{array}$ \\
\hline Kekuatan (Strengths) & & & & \\
\hline a. & Luas lahan area tanam & 22 & 4 & 0.19 & 0.77 \\
\hline b. & Usia produktif petani & 23 & 4 & 0.20 & 0.80 \\
\hline Kelemahan (Weaknesses) & & & & \\
\hline a. & Produktifitas lahan & 11 & 2 & 0.10 & 0.20 \\
\hline b. & Penerapan teknologi & 12 & 2 & 0.11 & 0.22 \\
\hline c. & $\begin{array}{l}\text { Riset yang berkaitan } \\
\text { dengan peningkatan }\end{array}$ & 12 & 2 & 0.11 & 0.22 \\
\hline d. & Penyimpanan pasca & 11 & 2 & 0.10 & 0.20 \\
\hline e. & Metedo pengeringan biji & 12 & 2 & 0.11 & 0.21 \\
\hline f. & Pengemasan pada & 11 & 2 & 0.10 & 0.20 \\
\hline & ToTAL & 114 & & 1.00 & 2.79 \\
\hline
\end{tabular}

\begin{tabular}{|l|l|l|l|l|l|}
\hline \multicolumn{1}{|c|}{ Faktor Internal } & $\begin{array}{c}\text { Jumla } \\
\text { h }\end{array}$ & $\begin{array}{c}\text { Bobot } \\
\text { Ratin } \\
\text { g }\end{array}$ & $\begin{array}{c}\text { Bobot } \\
\text { Skor }\end{array}$ \\
\hline Peluang (Opportunities) & & & & \\
\hline a. & $\begin{array}{l}\text { Semakin banyaknya } \\
\text { varian minuman olahan }\end{array}$ & 22 & 4 & 0.16 & 0.65 \\
\hline b. & Meningkatnya konsumsi & 15 & 3 & 0.11 & 0.33 \\
\hline c. & Banyaknya coffee & 16 & 3 & 0.12 & 0.35 \\
\hline d. & $\begin{array}{l}\text { Semakin banyaknya } \\
\text { generasi muda yang }\end{array}$ & 11 & 2 & 0.08 & 0.16 \\
\hline
\end{tabular}

\begin{tabular}{|l|l|l|l|l|l|}
\hline e. & Pasar produk kopi & 16 & 3 & 0.12 & 0.35 \\
\hline Ancaman (Threats) & & & & \\
\hline a. & $\begin{array}{l}\text { Kondisi harga dalam } \\
\text { negeri lebih tinggi }\end{array}$ & 22 & 4 & 0.16 & 0.65 \\
\hline b. & Suplai impor yang & 23 & 4 & 0.17 & 0.68 \\
\hline c. & Penguatan mata uang & 11 & 2 & 0.08 & 0.16 \\
\hline Total & 136 & & 1.00 & 3.33 \\
\hline
\end{tabular}

\section{Analisis Pembobotan}

Hasil pembobotan digunakan untuk perumusan strategi pada matriks SWOT daya saing kopi robusta, Setelah semua data yang mempengaruhi pengembangan agribisnis kopi robusta dikumpulkan, dilanjutkan kepada tahap analisis melalui model perumusan strategi dengan matriks SWOT. Dari hasil diatas dapat dilihat 3 bobot terbesar antara lain adalah luas lahan pertanian, usia produktif petani, dan suplai impor kopi yang meningkat. Sedangkan tiga bobot terendah antara lain adalah penguatan mata uang rupiah, semakin banyak generasi muda penikmat kopi, produktifitas lahan, penyimpanan pasca panen, dan metode pengeringan biji kopi (Tabel.3).

Tabel 3. Matriks SWOT strategi pengembangan produksi kopi Lampung

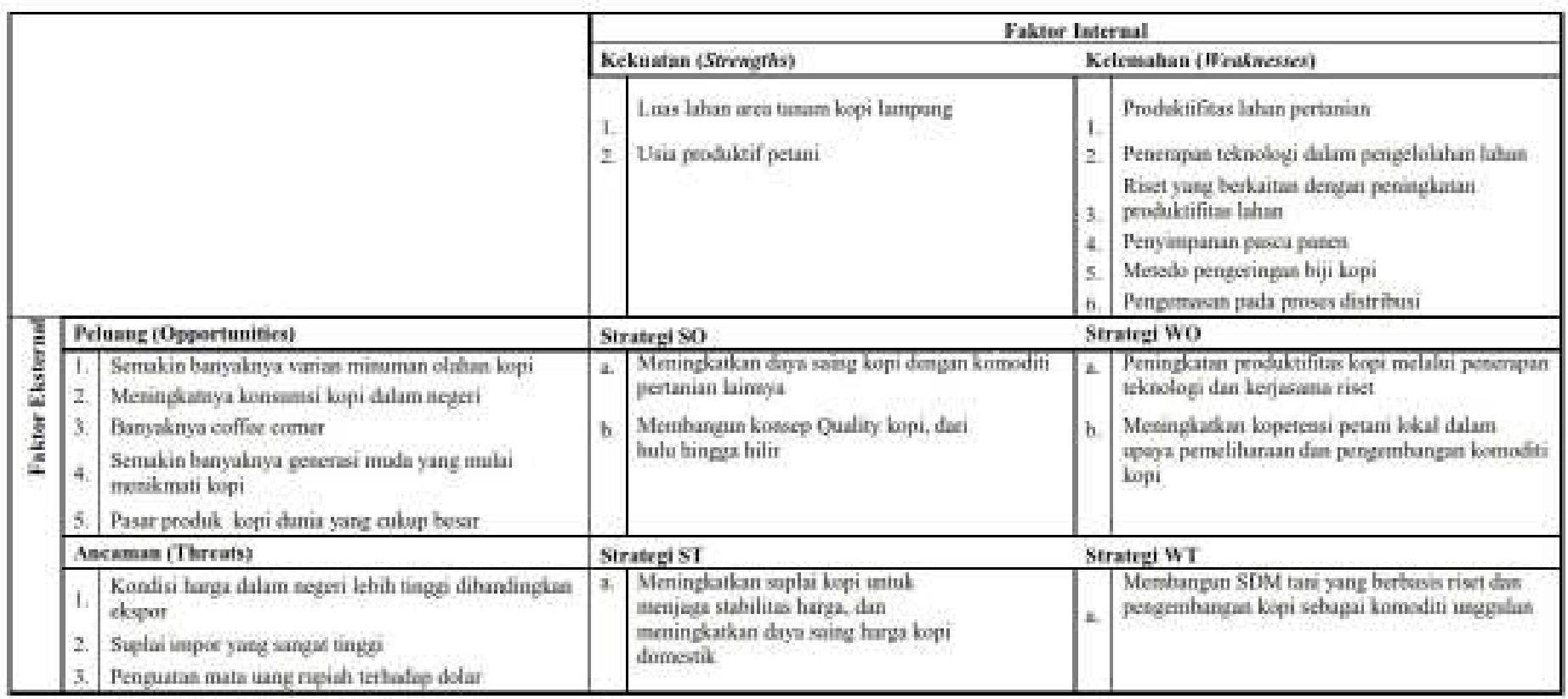




\section{Tahapan Pengambilan keputusan}

Dari perumusan strategi pada matriks, maka strategi yang dapat diterapkan dalam pengembangan kopi Lampung antara lain adalah:

a) Meningkatkan daya saing kopi dengan komoditi pertanian lainnya

b) Membangun konsep Quality kopi, dari hulu hingga hilir

c) Peningkatan produktifitas kopi melalui penerapan teknologi dan kerjasama riset

d) Meningkatkan kopetensi petani lokal dalam upaya pemeliharaan dan pengembangan komoditi kopi

e) Meningkatkan suplai kopi untuk menjaga stabilitas harga, dan meningkatkan daya saing harga kopi domestic

f) Membangun SDM tani yang berbasis riset dan pengembangan kopi sebagai komoditi unggulan.

\section{Kesimpulan}

Penerapan metode SWOT dalam strategi pengembangan daya saing produksi kopi Lampung menyimpulkan bahwa untuk meningkatkan produksi kopi lampung perlu dilakukan peningkatan daya saing kopi dengan hasil komoditi lampung lainnya, meningkatkan kualitas produksi kopi, meningkatkan produktifitas lahan, meningkatkan kompetensi petani dalam pengelolahan lahan dan produk kopi dan meningkatkan riset kopi yang bersifat menyeluruh untuk mengembangkan metode terbaik dalam setiap proses

\section{Daftar Pustaka}

AEKI, 2016. Ekspor Kopi. http://www.aekiaice.org/page/ekspor/id.

Bank Indonesia. 2019. Kurs Transaksi Bank Indonesia Mata Uang USD. http://www.bi.go.id

(Verified 30 Juni 2019).

Badan Pusat Statistik. Statistik kopi Indonesia catalog 5504006. www.bps.go.id. (Desember 2018) Dirjen Perkebunan. 2015-2019. Statistik Perkebunan Kopi Indonesia 2013- 2018. Jakarta.

FAO (Food and Agriculture Policy of United Nations). 2018. FAOSTAT Data Base, (online),

(http://faostat3.fao.org/home/index.ht ml\#DOWNLOAD, diakses 27 Desember 2018).

Hanani, N, et al. 2012. Persaingan Ekspor Kopi Indonesia Di Pasar International. Universitas Brawijaya. Indonesia.

International coffee organitation . 2019. Data as at july 2019, (online). http://www.ico.org/Market-Report-

19-20-e.asp

Rangkuti, Freddy. SWOT Balanced Scorecard: Teknik Menyusun Strategi Korporat yang Efektif plus Cara Mengelola Kinerja dan Risiko. Jakarta, Gramedia Pustaka Utama. 2011.

Saputri, Eni Dewi. Perancangan Strategi Pengembangan Usaha Dengan Metode SWOT Analisis di Perusahaan Abon Diamond Ampel Boyolali. 2011.

Tsivadze. 2011. Export Diversification in Georgia :Intensive and Extensive Margin. Master Thesis. International School of Economics at Tbilisi State University. Georgia 